\title{
Debt patterns of the peripheral economies of Europe: from the increased growth post-implementation of the Euro to the Great Recession
}

\author{
Yasmim Dalila Barbant* \\ Leonardo Flauzino de Souza ${ }^{\dagger}$
}

\begin{abstract}
The main purpose of this article is to outline the specificities of the indebtedness process of each country of the European periphery - Greece, Italy, Ireland, Portugal, and Spain - that guided the behavior of the demand and the indebtedness of the domestic economic agents from 2000 to 2017. The main results indicated that from 2000 to 2008, all of the countries had foreign sector surpluses (current account deficits), which characterized distinct indebtedness processes of the domestic economic agents. The reversal of these processes was accompanied by larger public deficits and the replacement of private debt with public debt. With the exception of Ireland, the positive impacts on the economic performance of these countries between 2009 and 2017 came from the foreign sector through the devaluation of the euro in the period.
\end{abstract}

Keywords: Eurozone crisis; Indebtedness; Keynesian economics.

JEL Classification: E12; F36; F45.

\footnotetext{
"Mestranda em Economia na Faculdade de Economia da Universidade Federal de Mato Grosso. Email: ydbarbant@gmail.com

+ Professor da Faculdade de Economia da Universidade Federal de Mato Grosso. Email: leo.flauzino@gmail.com, Agradecemos aos pareceristas anônimos da Brazilian Keynesian Review que fizeram importantes contribuições para melhoria do presente artigo.
} 


\section{Introduction}

The 2008 economic crisis made evident the deleterious effects of the processes of chronic indebtedness of private economic agents. These processes began in the 1980s with the advent of financialization (Epstein, 2005), money manager capitalism (Wray, 2009), or finance-led capitalism (Boyer, 2000; Guttmann and Plihon, 2010). Each of these expressions carries different theoretical meanings, but they start from the same accounting corollary: the expansion of markets and financial assets is only possible through the expansion of debt and other forms of liabilities.

For the eurozone countries, the process of indebtedness had different causes and consequences because of the specificities created by the institutional organization of the single European currency, which can be characterized by three elements: (i) deficits in current accounts stimulated by differences in the real exchange rates between eurozone countries (Bresser-Pereira and Rossi, 2015), (ii) financing expansion (and subsequent retraction) provided by global financial markets (Boyer, 2013; Hein, 2013; Özgür and Memis, 2017), and (iii) difficulties in coordinating the usual countercyclical monetary and fiscal policies (Bibow, 2013; Lavoie, 2015b).

The present study main purpose is to show the specificities of the indebtedness process of each country of the European periphery (Greece, Italy, Ireland, Portugal, and Spain - hereinafter referred to as GIIPS), which guided the expansion of demand (via consumption, investment, public expenditure, or netexport balance) and increased indebtedness of domestic economic agents (firms, households, and governments) in the pre-2008 crisis period and limited growth in the post-crisis period. In this sense, this article will present the indebtedness process caused by demand-led growth in each one of the GIIPS countries, showing that eurozone crisis is mainly a consequence of lack of demand, attenuated by small increases in net exports.

Hein (2013) classified the eurozone countries as debt-led consumption boom type (Greece, Ireland, and Spain), domestic demand-led type (Italy and Portugal), and export-led mercantilist type (Austria, Belgium, Finland, Germany, and Netherlands). The present study will focus on the first two groups of countries, with the aim of specifying the macroeconomic agents that sustained the expansion of demand with increasing indebtedness. The export-led mercantilist type increased could increased their growth in the pre-crisis period and presented growth limitations in the post-crisis. 
The current Keynesian analyses understand the eurozone crisis in three manners: a balance of payments crisis (Cesaratto, 2013, 2018); or the monetary sovereignty view (Febrero et al., 2018; Lavoie, 2015b, 2015a); or austerity policies after United States 2008 economic crisis contagion (Arestis and Karakitsos, 2012; Bibow, 2013).

The present study will show the dynamics of domestic and foreign indebtedness of public and private economic agents of the European periphery countries, before and after the crisis, showing that some of these structural characteristics are close to the views of Cesaratto $(2013,2018)$. However, for this study, the crisis of the European periphery countries and the change in the demandled growth components are not due to balance of payments constraints but rather to the restriction on liquidity imposed by the global financial markets from the contagion effect of the American crisis (Arestis and Karakitsos, 2012); combined with forced austerity policies at times of falling private spending (Bibow, 2013; Boyer, 2013; Lavoie, 2015b).

To better understand these issues, it is necessary to explore the orthodox theoretical view that implemented those policies. For Boyer (2013), the dynamic general equilibrium models are responsible for the austerity policies. In this paper, the main ideas responsible for those policies are: (i) the irrelevance of private indebtedness process - or the Modigliani-Miller hypothesis -; and (ii) the constant necessity of fiscal contraction - or the Ricardo-Barro hypothesis. In contrast, and explored in this paper, the Keynes-Minsky view demonstrates the indebtedness process is part of the economic cycle and there is a necessity of fiscal expansion to ease economic downturns.

In this sense, this paper differentiates from the above by presenting:

a) A discussion of orthodox theory that shaped economic policy in eurozone countries and its Keynesian critique looking at the principles that created the idea of irrelevance of private indebtedness and the needy for austerity policies;

b) An integrated Keynesian approach of economic cycle combining demand-led growth with public and mainly private indebtedness of eurozone periphery economic agents.

The main results of the study indicate that the reduction of the European recession began after the real devaluation of the euro and reduction in export deficits of the peripheral eurozone countries. Furthermore, the slow reduction in net export deficits, coupled with austerity policies, helps to explain the weak 
recovery of these economies, which - except for Ireland and Spain - have not yet returned to the gross domestic product (GDP) levels of 2008. At times when the private sector reduces spending to raise surpluses and initiate a process of debt reduction, reducing public deficits or generating surpluses will only be possible with current account surpluses (or foreign sector deficits).

To fulfill these objectives, in addition to this introduction and the conclusion, this article is divided into two sections: one is devoted to raising the theoretical debate about the meaning of indebtedness for the economic system, both orthodox and Keynesian; whereas the second section shows the demand-led growth characteristics, before and after 2008 economic crisis, that shaped the indebtedness process of public and private economic agents in each one of GIIPS countries.

\section{Theoretical aspects of the indebtedness process}

The indebtedness process described in the introduction section was influenced by a series of phenomena ranging from legal and institutional changes to variations in the economic policies after the 1980s. For all intents and purposes, the literature has characterized such process as the creation of a new modus operandi in global capitalism, guided by the financial system (Guttmann and Plihon, 2010; Hein, 2013; Wray, 2009).

There are theoretical conceptions inserted into mainstream economics that have subsidized these institutional, legal, and political transformations. According to Boyer (2013), the dynamic general equilibrium models reintroduced by the newclassical thinking would be mainly responsible for such interpretations especially in the European case - for the construction of the idea of optimal monetary zones (Mundell, 1961). However, regarding the understanding of indebtedness processes, the theoretical origins are distinct, although they are confirmed by the models of the new neoclassical synthesis.

Thus, the theoretical conceptions of mainstream economics about indebtedness can be summarized in four elements: (i) the irrelevance of private indebtedness (Modigliani-Miller hypothesis), (ii) choice of assets guided by a tradeoff between risk and return based on stochastic effects (Markowitz, 1952; Tobin, 1958), (iii) an understanding of the existence of a neutral financial system that performs only financial intermediation (Gurley and Shaw, 1955, 1956), and (iv) as a consequence of the other hypotheses, the existence of self-regulated markets (Fama, 1980). 
The Modigliani-Miller hypothesis can be presented as an irrelevance of (or indifference to) the manner of financing investment chosen by firms, among the various forms of credit, debt securities, or property titles (Modigliani and Miller, 1958). For this, one assumes the existence of perfect capital markets (all agents are price takers); maximizing rational behavior, with the portfolio manager who acquires the liabilities of the firms seeking to increase wealth; and perfect information (Miller and Modigliani, 1961). This conclusion is the result of the perception that a firm's entire debt supply is inevitably associated with the supply of physical capital, creating an explicit correlation between the returns on the new investment and dividend payments or servicing of the debt. Thus, the ModiglianiMiller hypothesis was responsible for creating the perception that increases in firms' indebtedness have no major implications for the economic system (Pasinetti, 2012).

The theoretical orientation given to the portfolio choice of the economic agent presumes a trade-off between return and risk, in which the return from a given portfolio is defined by an average of the returns of the various assets that compose it, and the risk is determined by a measure of dispersion relative to the average, leading the agent to choose an optimal portfolio that is inevitably diversified (Markowitz, 1952). In this case, the preference for more-liquid assets by economic agents could be expressed by changes in the agent's behavior in relation to their propensity (or aversion) to risk (Tobin, 1958).

The understanding of the financial system's role is exclusively related to financial intermediation; that is, capitation of resources from agents in surplus (savers) and financing of agents in deficit (Gurley and Shaw, 1956). Moreover, for Gurley and Shaw (1955), it is not necessary to consider the degree of liquidity of the various forms of debts issued by agents in deficit. Thus, financial institutions would assume the function of acquiring these forms of debt through the capitation of resources from saving agents, offering diverse financial services to these agents, which will be perceived by the savers as qualities that are more relevant than liquidity (Gurley and Shaw, 1955).

Finally, starting directly from the Modigliani-Miller hypothesis, Fama (1980) concluded that financial agents do not need to be regulated, since the principle of maximization guarantees the optimal choice. The conclusion of the author is a corollary resulting from the restrictive hypotheses presented by Miller and Modigliani (1961), the maximizing behavior that guarantees the diversification of portfolios, and a financial system that only performs financial intermediation 
through differentiation of financial products according to the services linked to them and not according to their degree of liquidity.

The understanding of a neutral financial system - as constructed by the aforementioned definitions - was well suited to an economic system of money neutrality, as proposed by the macroeconomic model of the new neoclassical synthesis (Goodfriend and King, 1997; Woodford, 2008, 2009). Thus, in this theoretical scope, it is the responsibility of the central bank to control the interest rates, as a method of influencing inflation in the short term, and to manage monetary aggregates to prevent inflation in the long term, whereas the financial system operates as a transmitter of these monetary policies, restricting or expanding credit.

In addition, if private indebtedness wasn't a major problem to economic system, public debt would become one. (Barro, 1974, 1989) sustains that, except in special occasions of market imperfections, government bonds can't be considered wealth creation, once there is no increase in the stock of capital. Indeed, this argument is very similar to Modigliani-Miller Hypothesis logic: private debt (or wealth) are associated to creation of stock of capital, once firms issue debt to generate investment. In other hand, following Barro's hypothesis, government issue debt because of budget deficits, i.e. government must repay the debt issued with tax increase in the future. Therefore, under Barro's hypothesis, governments must have constant budget surplus to repay debts issued is the past, creating the necessity of constant fiscal contraction.

In contrast, the post-Keynesian conception - centered on the ideas of Keynes and Minsky - offers a distinct interpretation of the aforementioned elements that is capable of explaining the constitution of chronic indebtedness processes and their main consequences. In the post-Keynesian theoretical scope, the increase in indebtedness arises from the portfolio choices (assets and liabilities) of economic agents; and crises are a natural consequence of the degree of exposure of these agents to excessive indebtedness (increase in liabilities). Thus, the two essential elements that differentiate this approach from the previous one are (i) choosing assets that involve a trade-off between pecuniary gains and liquidity (Kaldor, 1939; Keynes, 2013; Kregel, 1998) and (ii) the hypothesis of financial instability (Minsky, 2008a, 2008b).

In his original conception, Keynes established an asset choice theory that positioned money as the principal and only liquid asset, as opposed to capital goods and the stock of finished goods, thus making money the asset most demanded in 
times of high uncertainty, precisely because of its liquidity (Hicks, 1989). For a multi-asset environment, Kaldor (1939) established a hierarchy of liquidity, guiding the choice of assets according to the liquidity preference of economic agents: the greater the preference for liquidity, the greater the demand for liquid assets (Carvalho, 2013).

It is important to emphasize that even in this context of multiplicity of assets, money remains a special asset because it is able to acquire any other good or asset without the need for prior liquidation (Kregel, 1998). In other words, purchases and sales of assets involve transaction costs; therefore, having money means not paying such costs when selling an asset to obtain money (Davidson, 1978).

It is important to differentiate fully liquid assets (Davidson, 2009) or quasicurrencies (Minsky, 2008a) from the other financial assets. For Davidson (2009), these assets assume a high level of liquidity due to the presence of an institution that fixes short-term prices, making them almost fully convertible into money, depending on the institution's ability to honor the prices established by it. Thus, these assets are demanded by the economic agents as reserve assets; that is, they offer some pecuniary gains associated with their ownership (even if low), but they hinder speculative gains ${ }^{1}$ in the short term (Hicks, 1989).

Since every financial asset is, in accounting terms, a liability of an economic agent, the expansion of the supply of financial wealth depends on the expansion of the liabilities of the economic agents. This is a decision of mutual liquidity reduction, since borrowers will use the recently acquired money in the acquisition of less-liquid assets and financing agents will pass on the capitated money or create fiduciary money in the form of bank credit (Carvalho, 1999). Financial system, in this view, is not neutral. If banking system do not create fiduciary money, investment couldn't be financed. With no investment, there is no income or wealth increase.

In a manner, the same idea of accounting equivalence between assets and liabilities led to the construction of the Modigliani-Miller hypothesis. However, as emphasized by Minsky (2008b), the financial instability resulting from indebtedness is not linked to the amount of wealth but rather to the cash flows

${ }^{1}$ Speculative gains are understood to be the acquisition of an asset with the intention of future resale, that is, pecuniary gains obtained from the difference in current and future prices, without intermediation of derivative markets. In the presence of derivative markets, speculation should be understood as the absence of hedge operations (Farhi, 1999). 
generated by it. The decisions regarding indebtedness and asset choice involve exante aspects that may not be observed in the ex-post results (Kregel, 1976). Thus, the non-observance of expected results regarding the choice of assets or modifications in the commitments to be honored in the choices of indebtedness can compromise the solvency of one or more economic agents, precipitating movements of early liquidation of the forms of debt associated with these agents.

Then, for post-Keynesians, there is a natural cycle of indebtedness when, in a first moment, economic agents issue more debt to acquire more assets and/or pay for their financial deficit, expecting for higher returns in the future; and, in a second moment, if the their revenues do not increase in the amount expected, they will need to refinance previous debt. In this moment, changes in finance or banking agent's perceptions regarding current and future liquidity can trigger a financial crises because of credit restriction due lack of confidence (Lavoie, 2014), depending on the degree of convergence of the expectations of these agents. In other words, the greater the convergence of expectations of the economic agents in favoring liquidity (money and/or fully liquid assets instead of equities, private bonds or banking credit), the greater the impact on the agents most exposed to the need for renewal or obtaining of new financing.

In a macroeconomic perspective, it's possible to better understand those process analyzing the growth of aggregate demand components (consumption, investment, government expenditure, net exports) linked to financial results and indebtedness level of aggregate economic agents (households, firms, government, external sector). Thus, for example, if consumption if growing faster than GDP, households are in budget deficit and their indebtedness per GDP is increasing, it's feasible to imply a demand-led growth type centered on household indebtedness. In this case, when financial agents decrease their lending to households renew their debt, an economic downturn will be installed. The same conclusions can be made for investment and firms' indebtedness, government expenditures and public debt, and net exports and external finance.

When private economic agents become unwilling to expend (increase consumption or investment) or lend money (create indebtedness), governments must undertake a budget deficit position to soften economic downturns. If they follow the other way, adopting the Barro's hypothesis, they will worsen the recession by lack of aggregate demand.

Thus, by returning this theoretical idea to a specific historical situation, which in the case of this article refers to the eurozone, this study seeks to identify 
the agents chronically in deficit and involved in a process of persistent indebtedness that sustained the growth guided by the demand (Godley, 2012), before and after the crisis of 2008.

\section{Dynamics of the European Periphery ${ }^{2}$}

The adoption of a single European currency from the year 2000 onward accentuated divergences in economic performance resulting from specific structural characteristics of each economy (Bresser-Pereira and Rossi, 2015), which led to different growth dynamics. Countries with low inflation offered lower wage increases, which created a competitive cost advantage relative to countries with higher inflation (Bibow, 2013). These interpretations contribute to the understanding of external indebtedness processes and growth limits imposed by balance of payments constraints (Cesaratto, 2013; Thirlwall and McCombie, 2004). However, trade and current account deficits are more relevant to understanding the growth limits and the relative failure of the austerity policies than the characterization of liquidity constraints imposed by foreign financial systems, once the domestic financial systems are able to create liabilities in the single currency (Lavoie, 2015a).

The central argument of Bresser-Pereira and Rossi (2015) and Bibow (2013) lies in the evolution of the real exchange rates of GIIPS and Germany when considering only the eurozone's trading partners. In this case, as reported in Table 1, from 2000 to at least 2008, GIIPS exhibited a trend of real appreciation of domestic prices in relation to foreign prices, whereas Germany pursued devaluation. From 2009 onward for all GIIPS except Italy, and from 2012 onward for Germany, these trends reversed. On the other hand, when considering a larger group of trading partners, all the listed countries indicated a valuation trend up to 2008 and devaluation from 2009 to 2017.

In one hand, the increase in real exchange rates of the GIIPS from 2000 to 2008 limited the income growth of those countries. In Eurozone, the devaluation of Germany's real exchange rate (in labor cost) accelerated Germany income growth and contributed to the structural current account deficits of the GIIPS. On the other hand, from 2008 to 2017, the inversion of real exchange rate trajectory

${ }^{2}$ The data analysis covers the period from 2000 to 2017, due to it being the period for implementing the euro up until the last year with data available in the source consulted (Eurostat) when this article was being prepared and submitted - no results were observed for the year 2017 for any of the variables studied in this work. 
(in labor cost) - valuation of Germany and devaluation of GIIPS - expanded the net exports of GIIPS, or at least decreased the deficits, increasing their aggregate demand. Considering the real exchange rate (in price consumer index) calculated for the 37 trading partners, the Eurozone countries followed the same trajectory, valuation of real exchange rate from 2000 to 2008 and devaluation from 2008 to 2017, contributing to net exports decreasing in the first period, and expansion in the second. This phenomenon helps to explain external indebtedness process of GIIPS countries in the pre-2008 and the recovery, even if slow, in the post 2008.

Table 1. Index number evolution (base year: 2005) of the real exchange rates in Consumer Price Index and unit labor cost of GIIPS and Germany in relation to the Eurozone and the group of the 37 largest trading partners ${ }^{3}$

\begin{tabular}{|c|c|c|c|c|c|c|c|}
\hline \multirow{2}{*}{$\begin{array}{c}\text { Trading } \\
\text { Block }\end{array}$} & \multirow{2}{*}{$\begin{array}{c}\text { Country } \\
\text { (Region) }\end{array}$} & \multicolumn{3}{|c|}{ Consumer Price Index } & \multicolumn{3}{|c|}{ Labor Cost } \\
\hline & & 2000 & 2008 & 2017 & 2000 & 2008 & 2017 \\
\hline \multirow{6}{*}{ 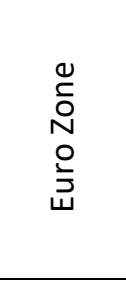 } & Germany & 106,3 & 100,6 & 99,8 & 119,8 & 98,3 & 108,0 \\
\hline & Greece & 88,7 & 96,0 & 93,1 & 82,6 & 96,2 & 82,4 \\
\hline & Italy & 98,1 & 99,4 & 100,0 & 88,1 & 98,4 & 97,9 \\
\hline & Ireland & 97,8 & 105,4 & 94,8 & 99,4 & 120,0 & 72,7 \\
\hline & Portugal & 97,0 & 101,3 & 100,5 & 99,6 & 101,6 & 94,6 \\
\hline & Spain & 92,4 & 100,0 & 98,8 & 89,9 & 104,1 & 90,5 \\
\hline \multirow{7}{*}{ 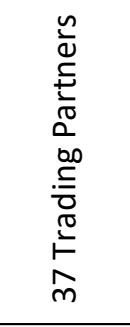 } & Euro Zone & 84,4 & 106,5 & 98,4 & 83,8 & 104,1 & 98,1 \\
\hline & Germany & 96,4 & 103,9 & 98,7 & 106,0 & 100,7 & 104,8 \\
\hline & Greece & 85,2 & 98,1 & 94,9 & 78,6 & 97,5 & 82,4 \\
\hline & Italy & 90,8 & 102,7 & 99,1 & 81,5 & 100,7 & 96,9 \\
\hline & Ireland & 83,8 & 109,1 & 90,8 & 85,3 & 122,2 & 70,2 \\
\hline & Portugal & 90,9 & 103,0 & 99,6 & 93,8 & 102,7 & 93,6 \\
\hline & Spain & 85,9 & 102,0 & 98,2 & 83,6 & 105,3 & 89,9 \\
\hline
\end{tabular}

Source: Eurostat; own preparation.

As stated earlier, processes of chronic foreign indebtedness in the eurozone are not necessarily interrupted by a lack of foreign financing due to the capacity for endogenous creation of financing in the single currency. In the period of stability between 2000 and 2008, the process of financial liberalization or deregulation permitted the convergence of interest rates to lower levels, thus expanding credit and other forms of financing created by recent financial innovations (Arestis and Karakitsos, 2012). The inflationary stability after the introduction of the euro, together with the process of financial liberalization, led to the formation of

\footnotetext{
${ }^{3}$ The real exchange rates are calculated in two blocks of countries: Eurozone and 37 trading partners. The Eurozone countries considers the 19 Euro area member states; and the 37 trading partners considers the 28 European Union members plus Australia, Canada, United States, Japan, Norway, New Zealand, Mexico, Switzerland and Turkey.
} 
household credit bubbles based on consumption and the real estate market (Boyer, 2013), in addition to financial asset bubbles (Özgür and Memis, 2017).

Table 2. Average growth and rate for share of the GDP and main components of demand from 2000 to 2017

\begin{tabular}{|c|c|c|c|c|c|c|}
\hline & \multirow{2}{*}{ GDP and Components } & \multicolumn{2}{|c|}{ Geometric Rate of Growth } & \multicolumn{3}{|c|}{ Share of GDP } \\
\hline & & 2000-2008 & 2008-2017 & 2000 & 2008 & 2017 \\
\hline \multirow{6}{*}{$\begin{array}{l}\text { U } \\
\text { 岀 } \\
\text { 怘 }\end{array}$} & GDP & $3,49 \%$ & $-3,16 \%$ & $100 \%$ & $100 \%$ & $100 \%$ \\
\hline & Government Consumption & $3,53 \%$ & $-2,75 \%$ & $21,0 \%$ & $21,0 \%$ & $22,0 \%$ \\
\hline & Household Consumption & $3,92 \%$ & $-3,39 \%$ & $65,9 \%$ & $67,9 \%$ & $67,1 \%$ \\
\hline & Investment & $4,04 \%$ & $-9,17 \%$ & $23,2 \%$ & $24,1 \%$ & $13,7 \%$ \\
\hline & Exports & $3,91 \%$ & $0,24 \%$ & $23,2 \%$ & $23,9 \%$ & $32,9 \%$ \\
\hline & Imports & $4,87 \%$ & $-3,62 \%$ & $33,3 \%$ & $36,9 \%$ & $35,7 \%$ \\
\hline \multirow{6}{*}{$\begin{array}{l}\text { 京 } \\
\underline{E}\end{array}$} & GDP & $0,89 \%$ & $-0,51 \%$ & $100 \%$ & $100 \%$ & $100 \%$ \\
\hline & Government Consumption & $1,15 \%$ & $-0,35 \%$ & $19,1 \%$ & $19,5 \%$ & $19,9 \%$ \\
\hline & Household Consumption & $0,65 \%$ & $-0,23 \%$ & $59,7 \%$ & $58,6 \%$ & $60,3 \%$ \\
\hline & Investment & $1,65 \%$ & $-3,02 \%$ & $20,9 \%$ & $22,2 \%$ & $17,7 \%$ \\
\hline & Exports & $2,35 \%$ & $1,57 \%$ & $23,6 \%$ & $26,5 \%$ & $32,0 \%$ \\
\hline & Imports & $2,64 \%$ & $0,67 \%$ & $23,3 \%$ & $26,7 \%$ & $29,9 \%$ \\
\hline \multirow{6}{*}{ 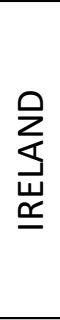 } & GDP & $4,29 \%$ & $5,12 \%$ & $100 \%$ & $100 \%$ & $100 \%$ \\
\hline & Government Consumption & $3,34 \%$ & $-0,19 \%$ & $21,9 \%$ & $20,8 \%$ & $12,5 \%$ \\
\hline & Household Consumption & $4,89 \%$ & $0,50 \%$ & $45,6 \%$ & $48,8 \%$ & $31,3 \%$ \\
\hline & Investment & $4,43 \%$ & $5,2 \%$ & $24,1 \%$ & $24,8 \%$ & $24,1 \%$ \\
\hline & Exports & $5,11 \%$ & $8,7 \%$ & $86,3 \%$ & $94 \%$ & $122 \%$ \\
\hline & Imports & $5,65 \%$ & $5,77 \%$ & $77,9 \%$ & $88,2 \%$ & $90 \%$ \\
\hline \multirow{6}{*}{ 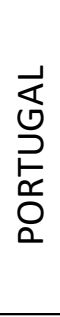 } & GDP & $1,07 \%$ & $-0,14 \%$ & $100 \%$ & $100 \%$ & $100 \%$ \\
\hline & Government Consumption & $1,77 \%$ & $-0,74 \%$ & $19,4 \%$ & $20,6 \%$ & $19,6 \%$ \\
\hline & Household Consumption & $1,38 \%$ & $-0,25 \%$ & $62,4 \%$ & $64,3 \%$ & $64,1 \%$ \\
\hline & Investment & $-0,72 \%$ & $-3,28 \%$ & $26,8 \%$ & $23,4 \%$ & $17,6 \%$ \\
\hline & Exports & $4,05 \%$ & $4,23 \%$ & $24,1 \%$ & $30,5 \%$ & $45,2 \%$ \\
\hline & Imports & $3,16 \%$ & $1,85 \%$ & $32,8 \%$ & $38,7 \%$ & $46,6 \%$ \\
\hline \multirow{6}{*}{$\frac{z}{\frac{a}{a}}$} & GDP & $3,25 \%$ & $0,18 \%$ & $100 \%$ & $100 \%$ & $100 \%$ \\
\hline & Government Consumption & $5,21 \%$ & $0,27 \%$ & $16,3 \%$ & $18,9 \%$ & $19,1 \%$ \\
\hline & Household Consumption & $2,92 \%$ & $-0,35 \%$ & $58,3 \%$ & $56,7 \%$ & $54,1 \%$ \\
\hline & Investment & $4,51 \%$ & $-2,49 \%$ & $26,1 \%$ & $28,8 \%$ & $22,6 \%$ \\
\hline & Exports & $3,32 \%$ & $3,11 \%$ & $25,4 \%$ & $25,5 \%$ & $33,1 \%$ \\
\hline & Imports & $5,05 \%$ & $-0,23 \%$ & $26,1 \%$ & $29,9 \%$ & $28,8 \%$ \\
\hline
\end{tabular}

Source: Eurostat; own preparation.

Thus, in order to identify the indebtedness process of each of GIIPS, the following will be analyzed: (i) the dynamics of demand components, following the Keynesian theoretical aspects to explain the short-term fluctuations (Amitrano, 2013), and (ii) the financial results of the main aggregate economic agents, to show which ones are involved in a process of chronic indebtedness (Godley, 2012). Those 
elements will help to understand the demand expansion of each one of GIIPS countries and the growth limits imposed by lack of private demand, when private agents couldn't increase their debt anymore, and insufficient public expending caused by austerity policies.

The period of analysis is from 2000 to 2017 , depending on data availability, and considering the 2008 crisis as a disruptive moment. There are other important moments to categorize the eurozone crisis as mentioned by Allen and Moessner (2012), but they all happen after 2008 economic crisis, therefore, this paper considers that the instability period had begun in 2008 and extended a decade long.

\subsection{Greece}

The economic performance of Greece between 2000 and 2008 was a result of the growth of domestic absorption, especially consumption and investment (Table 2). The country was unable to adhere to the convergence criteria of the eurozone, in particular regarding structurally higher inflation, which led to wage increases above productivity growth, thus limiting aggregate profits and widening the export deficit (Bibow, 2013). From 2008 to 2017, the Greek depression marked the fall in all components of demand, especially investment, thus reducing the export deficit (Table 2) at the expense of unemployment and strong contraction in wages (Bibow, 2013; Boyer, 2013; Bresser-Pereira and Rossi, 2015).

Figure 1 shows that the ratio of the financial accounts between the government and the foreign sector is chronically inverted - between 2000 and 2008 , the flows of public deficits were oriented toward the foreign sector. From 2008 onward, following the trajectory of devaluation of the euro and devaluation of labor costs, which reduced the exchange rates in foreign prices per domestic prices (Table 1), the surplus of the foreign sector (deficit in current accounts) was gradually reduced, inverting its position in the period of 2013-2017. From 2000 to 2017, companies and households had an inverse relationship, with households occupying a deficit position and non-financial corporations remaining in surplus. From 2000 to 2008, the financial sector accumulated modest surpluses, except for 2007; however, after 2008, it began to accumulate larger surpluses, fueled by the public deficit. 
Figure 1. Greece: Financial results per aggregate economic agent in relation to GDP

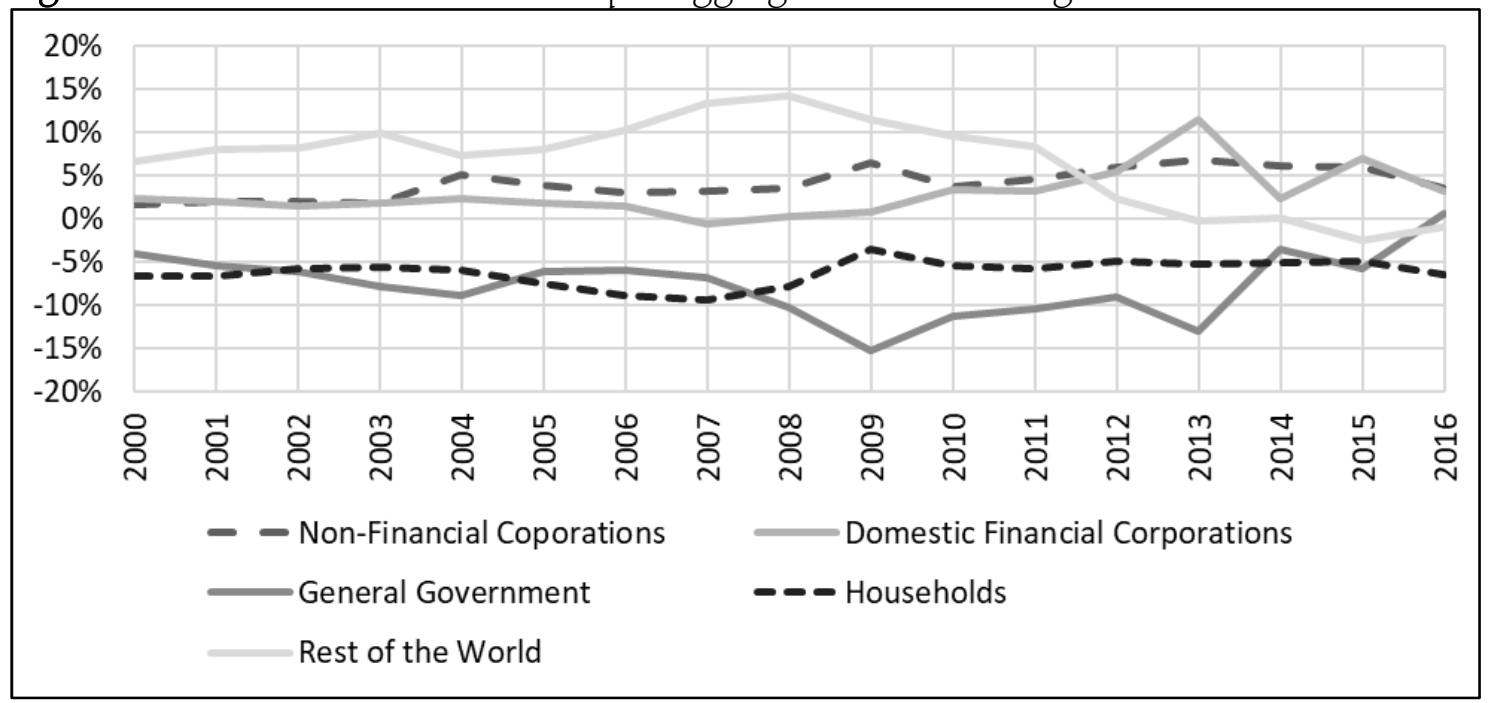

Source: Eurostat; own preparation.

The scenario described above (and summarized in Figure 1) shows that between 2000 and 2008, there were two unsustainable processes in the Greek economy, as originally developed by Godley (2012): chronic private deficit (households) and chronic surplus in the foreign sector (chronic deficit in current accounts) - given the characteristics of the single currency, the latter is less relevant if it is fully constituted within the eurozone (Febrero et al., 2018; Lavoie, 2015a).

The reversal of these processes - triggered in the post-2008 period - was incomplete. On one hand, the devaluation of the euro and labor costs allowed the reduction of foreign sector surpluses; however, economic depression, falling wages, and unemployment prevented household's surpluses. Furthermore, in the post2008 period, the public deficit was oriented toward the financial sector - an economic agent that did not have persistent deficits but suffered from liquidity problems (Allen and Moessner, 2012).

Greece's entry into the eurozone facilitated the process of financial integration that allowed the scaling of the debts of the Greek financial sector and foreign sector; that is, it facilitated the increase in liabilities of financial companies and the borrowing of non-residents in the Greek financial system - as seen in Figure 2 - with the expansion of the liabilities of these agents between 2002 and 2012. The same scenario enabled the obtaining of easy credit for the households that financed their deficits (Figure 1) with chronic expansion of their liabilities (Figure 2). This scenario reversed in 2012 with the massive expansion of public 
indebtedness to rescue the financial sector, which had chronic liquidity difficulties (Allen and Moessner, 2012).

Figure 2. Greece: Total liabilities per aggregate economic agent in relation to GDP

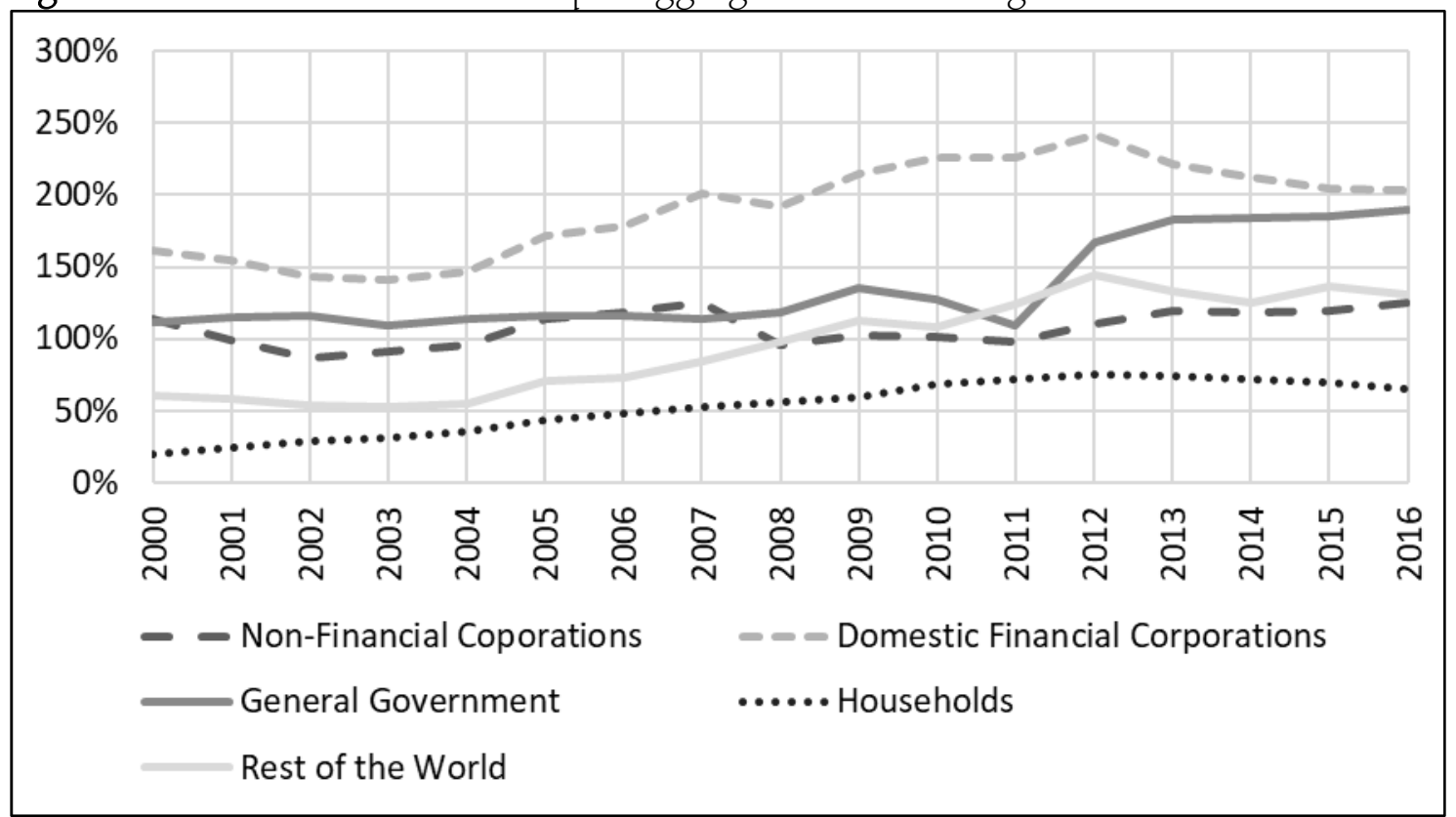

Source: Eurostat; own preparation.

\subsection{Italy}

Italy's economic growth from 2000 to 2008 was due to the expansion of public spending and investment. Although export growth was slightly higher than the previous variables, imports grew at a faster rate, such that the Italian export balance was on average close to zero (Table 2). This process accompanied the aforementioned appreciation of the euro between 2000 and 2008, contributing to the increase in imports. From 2008 to 2016, the Italian recession was marked by the fall in all domestic demand variables, offset by a small increase in the export balance (Table 2).

In the financial accounts (Figure 3), the relationship between the position of the government and non-financial corporations is inverted, particularly between 2000 and 2010. Even though both were chronically in deficit, the sectors behaved antagonistically. From 2008 onward, accompanying the exchange rate trajectory, companies began reducing their deficits, moving toward surplus, which was reached in 2013. Part of the reversal of the position of the business sector is a consequence of the inversion of the position of the foreign sector after 2011, allowing the public deficit to also be absorbed by households, which were systematically reducing their surpluses. 
Figure 3. Italy: Financial results per aggregate economic agent in relation to GDP

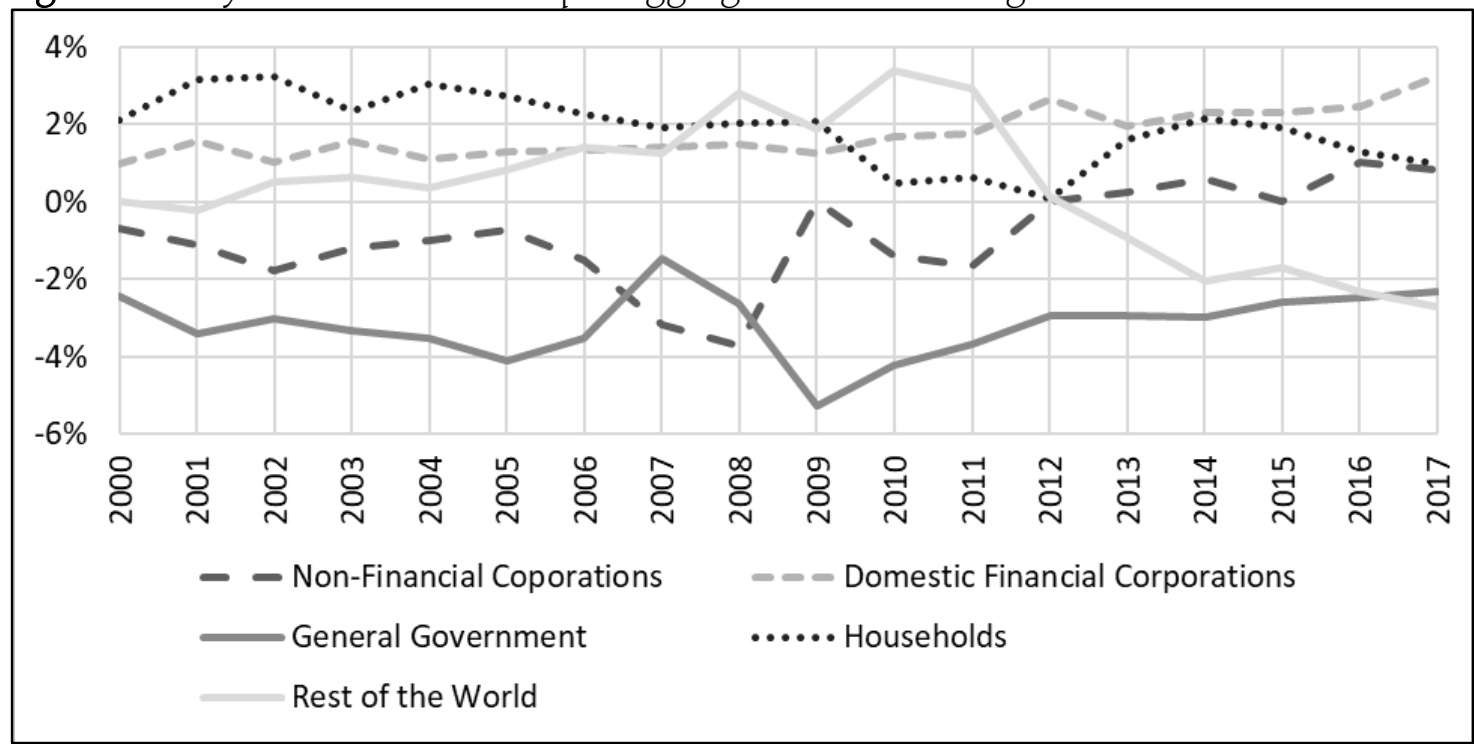

Source: Eurostat; own preparation.

For Italy (Figure 4), non-financial corporations and domestic financial sector were the most-indebted agents, accompanied by the government and the foreign sector. For non-financial corporations and government, these effects are consistent with the financial results shown in Figure 3; that is, the agents that are chronically in deficit increased their indebtedness. The systematic reduction of household surpluses up until 2012 was accompanied by an increase in their indebtedness, thus reinforcing the expansion of consumption. On the other hand, the financial sector (chronically in surplus) and the foreign sector (in surplus from 2000 to 2012) also exhibited effects of debt expansion, which, in this case, can be characterized as processes of borrowing to acquire assets.

Thus, it is feasible to classify Italy as domestic demand-led (Hein, 2013) the increase in indebtedness had little impact on GDP growth in the crisis period (Özgür and Memis, 2017), mainly due to the low productivity growth (Bibow, 2013). In the post-2008 period, the Italian recession was the result of the imposition of austerity measures that created restrictions for the expansion of domestic demand, minimally offset by the growth of exports. 
Figure 4. Italy: Total liabilities per aggregate economic agent in relation to GDP

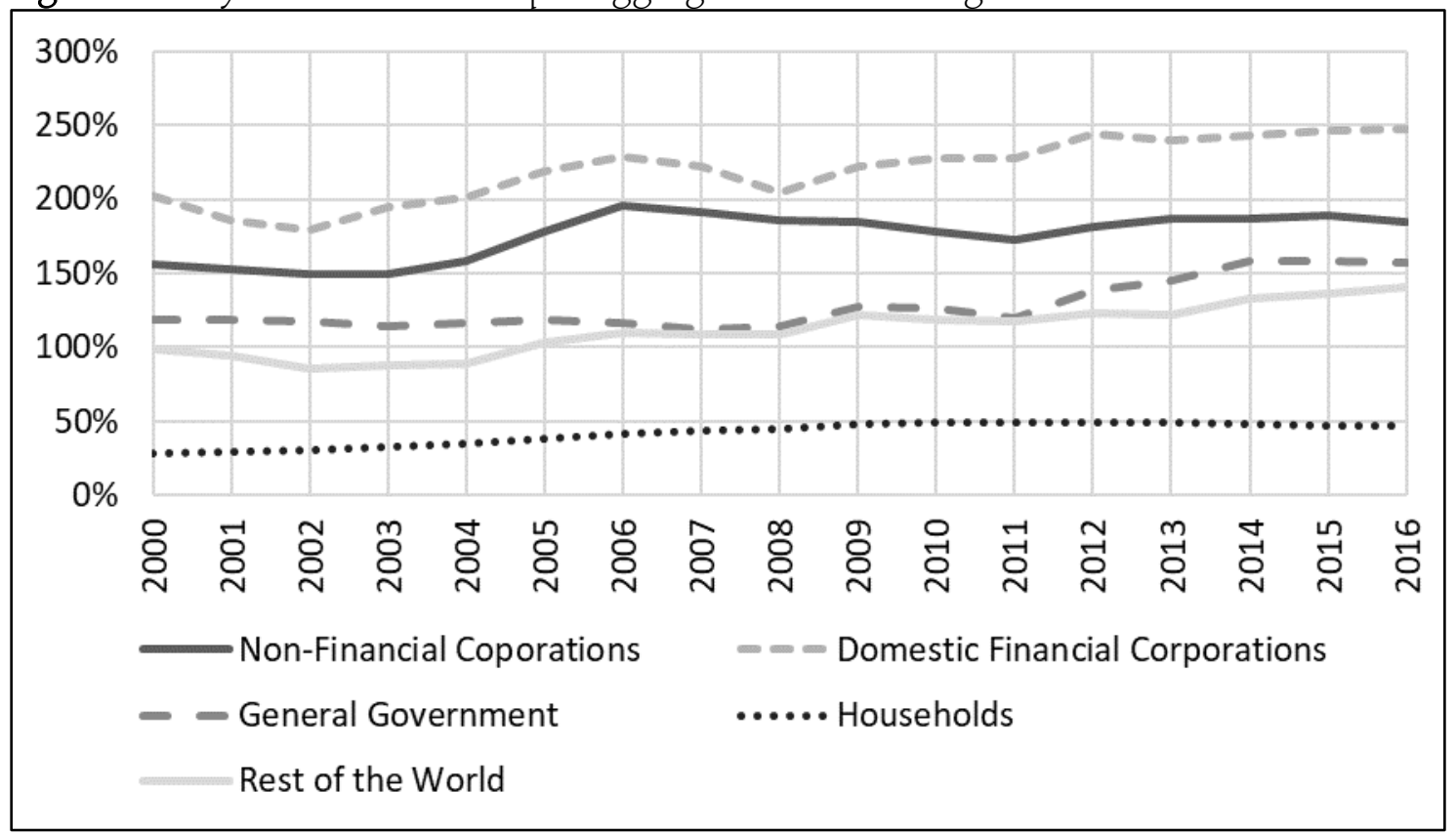

Source: Eurostat; own preparation.

\subsection{Ireland}

Ireland's economic performance (Table 2) from 2000 to 2008 was a consequence of the expansion of household consumption and firm investment. Although exports also grew significantly in the period, the average growth of imports was higher, such that the export balance decreased. In the period from 2008 to 2017, the fiscal contraction - which represented an average annual reduction of $0.44 \%$ in public spending, reducing its share of GDP from 20.8 to $12.5 \%$ - was offset by the strong expansion of investments and exports. In the same period, the low growth in household consumption was associated with high household indebtedness (Boyer, 2013).

The expansion of credit and real estate lending, which led to the onset of a real estate crisis in Ireland, can be characterized by the deficit position of households up until 2008 (Boyer, 2013). The increase in the public deficit - which helped in the recovery of the surplus position of households - generated much greater gains in the financial sector. The foreign sector and companies have an inverse relationship in the financial accounts, especially after 2004. Between 2004 and 2010, the foreign sector - which was already in surplus - accumulated more assets, thus increasing its surplus. In 2009, this relationship exhibited signs of reversal, and after 2010, the positions changed as the euro depreciated (Table 1). 
Figure 5. Ireland: Financial results per aggregate economic agent in relation to GDP

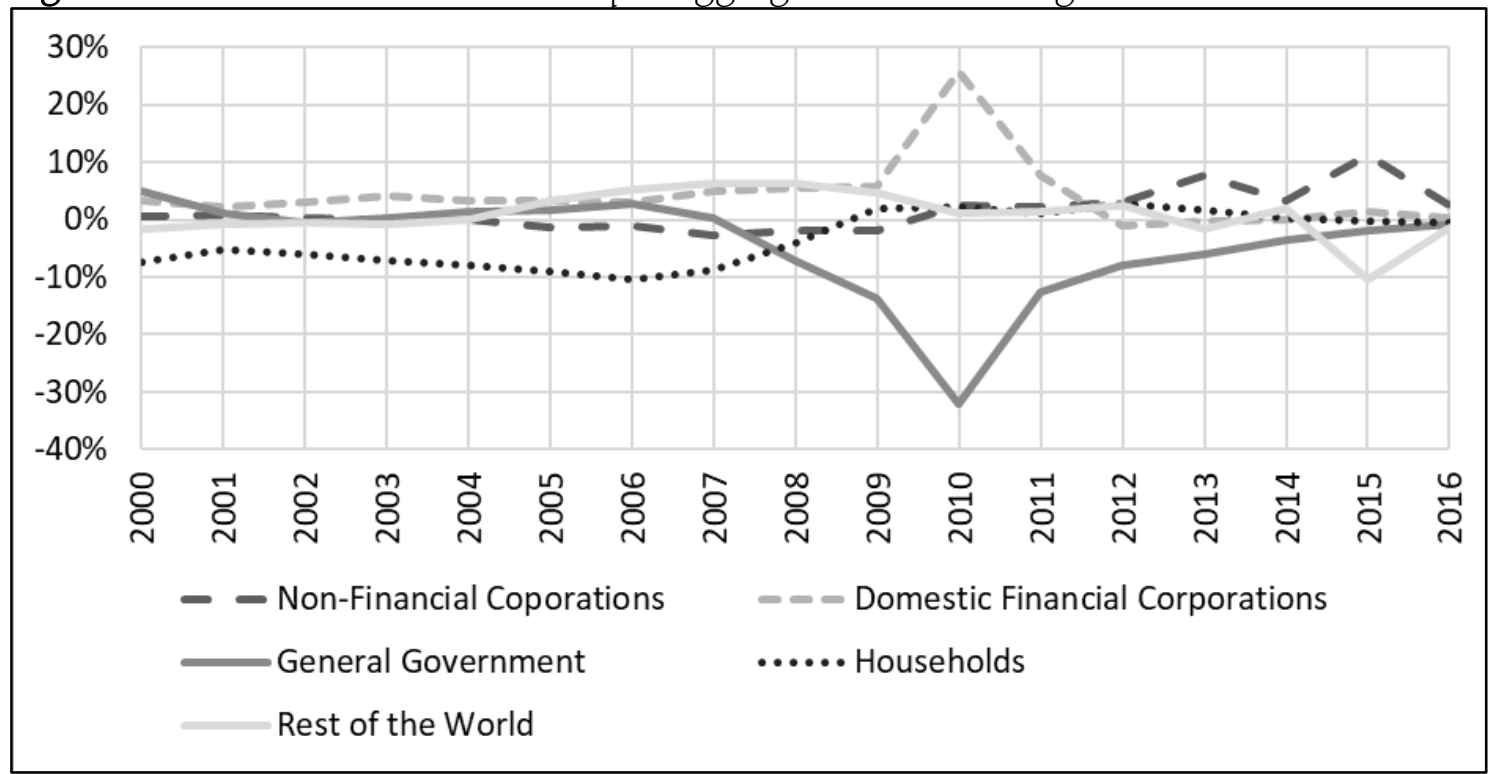

Source: Eurostat; own preparation.

Figure 6 shows a scenario of extreme leveraging of Irish economic agents: the financial sector and the foreign sector accumulated liabilities that exceeded $2000 \%$ of the Irish GDP, reflecting the greater financial integration afforded by the liberalization processes. The debts of households and government also significantly increased: the former in the pre-2008 period, with the expansion of consumption and real estate acquisition, and the latter in the post-2008 period, in the process of replacing toxic private debts in the financial sector with public debt.

Also notable was the explosion of corporate debt in the post-2008 period as highlighted above, Irish GDP growth in this period was generated by the significant expansion of investment, with average annual growth of $5.2 \%$ (Table 2 ). In other words, the acquisition of physical assets was massively financed by the constitution of debts and/or equity share, which indicates the formation of a potentially unsustainable process (Godley, 2012).

Ireland's classification as debt-financed consumption is feasible for the precrisis period, although the effects of the expansion in investments over the same period - and especially in the post-crisis period - cannot be neglected, particularly given the high productivity growth (Bibow, 2013). However, the Irish growth is based on the expansion of corporate debt, which already exceeds $600 \%$ of GDP in an economy with high global financial integration - elements that can trigger a sharp reversal of the current growth trajectory. 
Figure 6. Ireland: Total liabilities per aggregate economic agent in relation to GDP

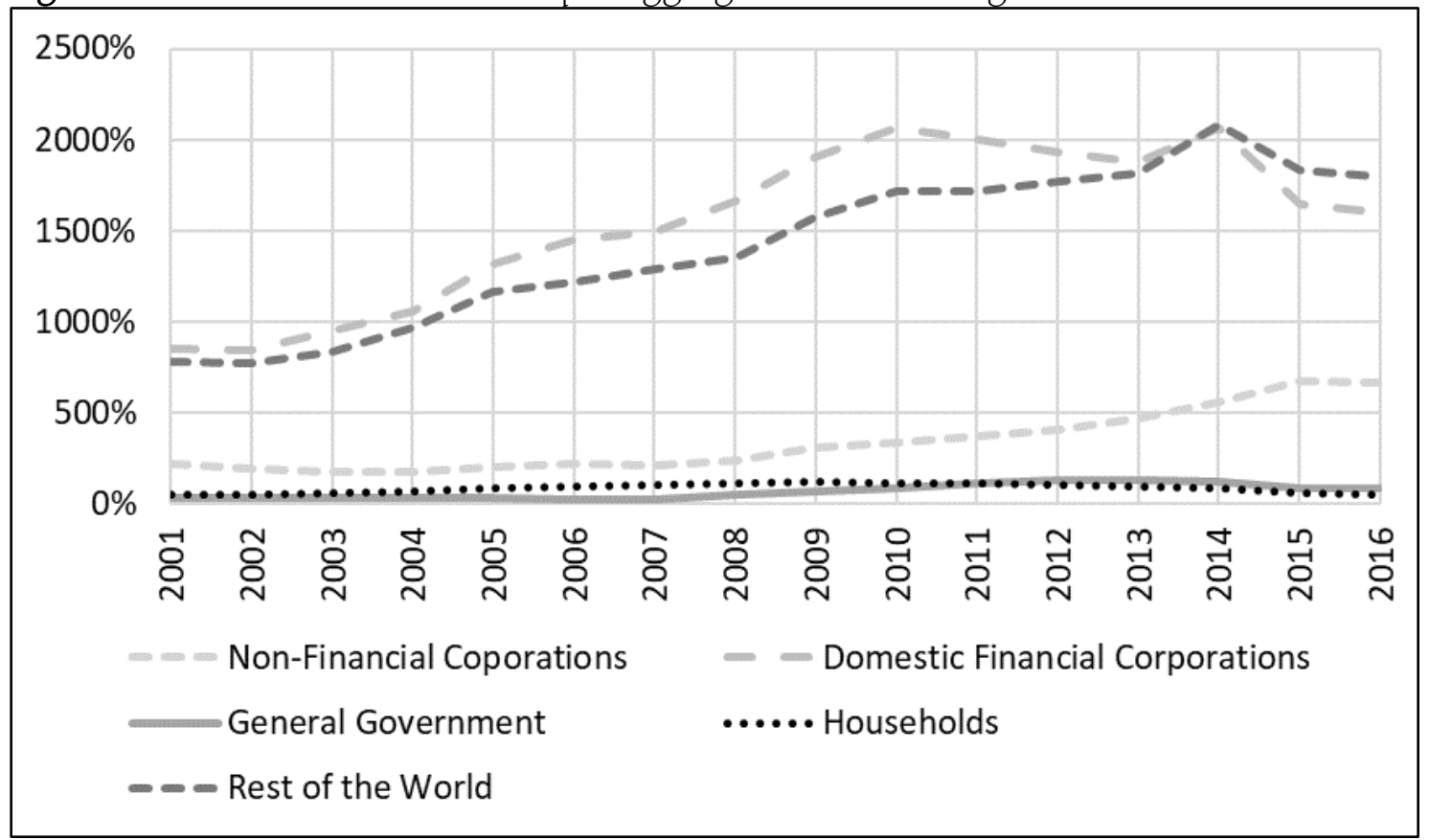

Source: Eurostat; own preparation.

\subsection{Portugal}

For Portugal from 2000 to 2008, although exportation was a relevant variable, given that it had the highest growth rate among the components of demand during the whole period, increasing its average share in GDP (Table 2), the high growth of imports mitigated the reduction in trade deficits. The modest GDP growth in the period came from the expansion of household consumption and public spending. The Portuguese recession, from 2008 to 2017, was marked by the fall in domestic absorption, with emphasis on the fall in investments, which represented a reduction of almost $5 \%$ per year in the period.

The ratio of financial accounts between the foreign sector and non-financial corporation is inverted (Figure 7). From 2000 to 2008, the foreign sector accumulated financial and physical assets, increasing its surpluses with Portugal a tendency that was reversed from 2009 onward. Non-financial corporations were chronically in deficit, accumulating debts and other forms of liabilities. After the crisis of 2008, the trajectories were reversed: companies gradually reduced their deficits and attained surpluses in 2012, whereas the foreign sector came to be in deficit. Therefore, up until 2012, the process of foreign indebtedness was fueled by the deficit position of the non-financial corporations in the need to finance the negative export balance, even with the growth of exports as the main demand factor. 
Figure 7. Portugal: Financial results per aggregate economic agent in relation to GDP

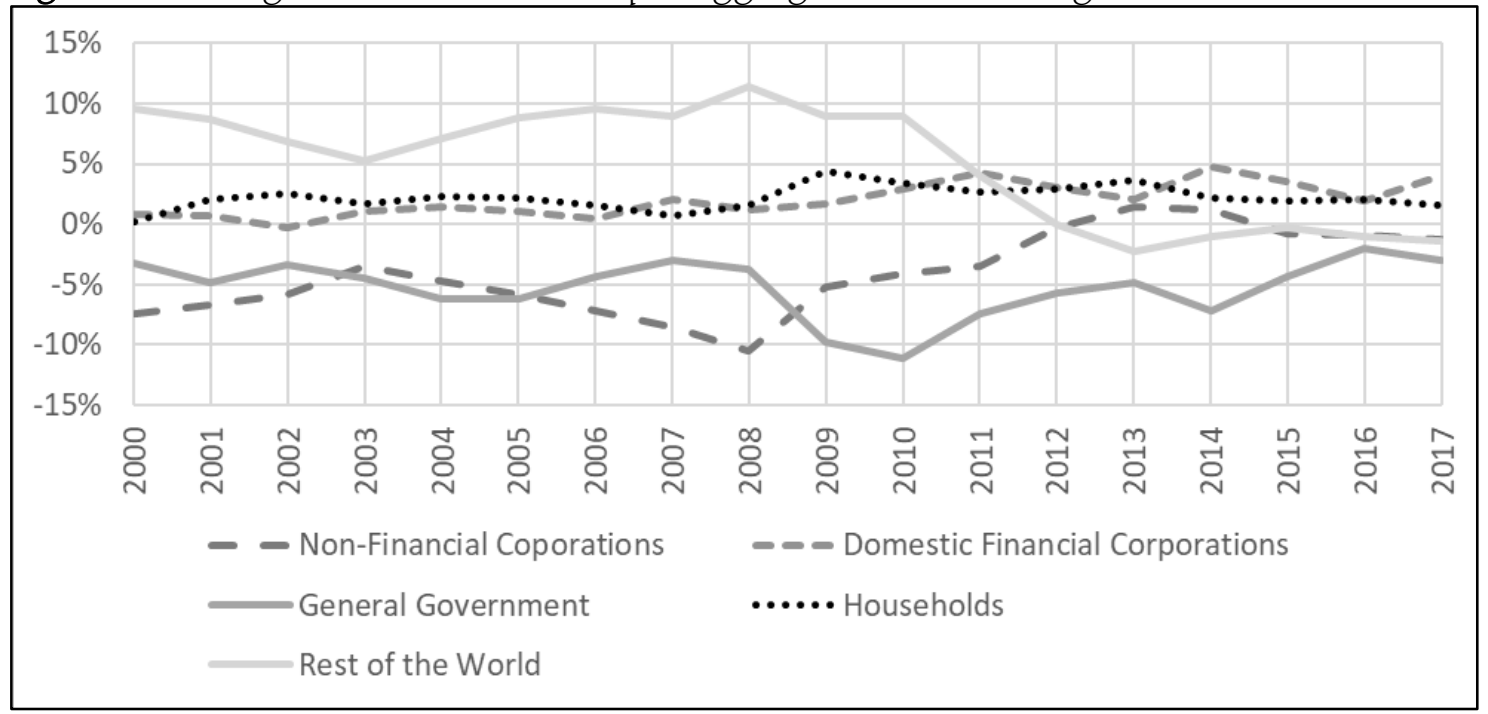

Source: Eurostat; own preparation.

This behavior accompanied the exchange rate trajectory (Table 1): at the time of exchange rate appreciation (in domestic prices per external prices) between 2000 and 2008, Portuguese firms increased their indebtedness and the foreign sector accumulated assets, whereas at the time of exchange rate depreciation between 2009 and 2017, the Portuguese economy reduced its need for foreign financing to the same extent that Portuguese companies reduced their overall financing need. The government maintained a deficit over the whole period, even with the average reduction in spending between 2008 and 2017 - its deficits were essentially absorbed by households and the financial sector, both of which were chronically in surplus.

Figure 8 shows that private indebtedness (companies and the financial sector) and indebtedness of foreign agents increased between 2000 and 2008 - a result of the financing bubble fueled by financial liberalization (Boyer, 2013). On the other hand, the public indebtedness proved to be stable between the postinsertion of the euro up until the 2008 crisis. After the crisis, a process of substituting private debts with public debt began; this process was characterized by a significant reduction in the financial sector's debt and, to a lesser degree, the corporate debt, with an increase in public debt. 
Figure 8. Portugal - Total liabilities per aggregate economic agent in relation to GDP

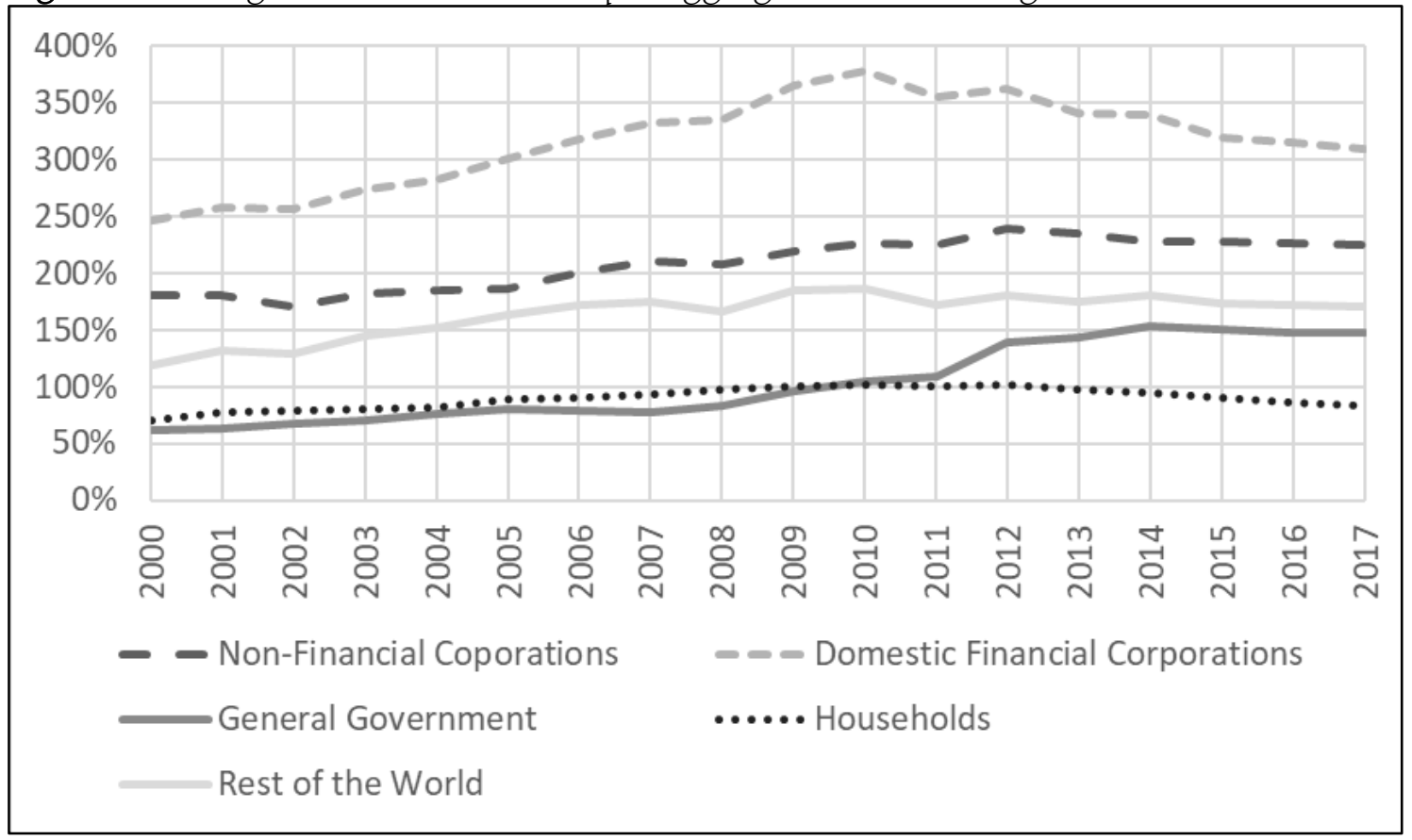

Source: Eurostat; own preparation.

Hein (2013) characterized the Portuguese economy as an economy driven by domestic demand. However, the growth of the demand components (Table 2) clearly shows the importance of Portugal's insertion in international trade. On the other hand, Bibow (2013) emphasized that although Portugal had productivity growth similar to Germany in the pre-crisis period, the pace of wage growth in the Portuguese economy well above productivity would have triggered its process of foreign indebtedness (current account deficits).

However, even though the real exchange rates within the eurozone of Germany and Portugal had followed different paths in the pre-crisis (Table 1), which would justify the argument of Bibow (2013), this was insufficient for the import growth rate to surpass, on average, the export growth rate in the same period (Table 2). The reversal of the euro's appreciation trajectory in the post-crisis period was sufficient to reverse the trajectory of Portuguese foreign indebtedness.

The unusual feature of the process of Portuguese indebtedness is the expansion of corporate liabilities (Figure 8), with no correlation with the expansion of investment (Table 2) and with an export growth rate higher than for imports. Özgür and Memis (2017) found a positive correlation between credit expansion and increase in stock prices of Portuguese companies, which could indicate a process of debt expansion for the acquisition of financial assets. However, to corroborate such a conclusion, it would be necessary to analyze the evolution of 
the asset structure of Portuguese companies, which is not the subject of this present study.

\subsection{Spain}

The economic performance of Spain in the pre-crisis period was due to the expansion of domestic absorption, especiallygovernment spending and investment. The appreciation of the euro between 2000 and 2008 contributed to a reduction in the Spanish export balance, from a deficit of less than 1\% of GDP to a deficit of more than $4 \%$, due to the higher growth of imports relative to exports (Table 2). The reverse scenario in the post-2008 period was characterized by recession, near zero growth in public spending, and decreasing consumption and investment offset by export expansion and a strong contraction of imports, which generated an export balance in 2016 of more than 4\% of GDP.

In the financial accounts of the Spanish economy (Figure 9), up until 2007, household and corporate deficits were responsible for reducing the public deficits, attaining a surplus between 2005 and 2007, and for increasing the surpluses of the foreign sector. The reversal of 2008 - accompanied by the inflection of the exchange rate - inverted the position of the foreign sector and allowed the high public deficits to migrate to the private sector (households and non-financial corporations), causing them to obtain surpluses in the post-2008 period. It is important to note that unlike previous examples, the Spanish financial sector maintained modest surpluses, except for 2012, which was due to the lack of liquidity mentioned above (Allen and Moessner, 2012).

Figure 9. Spain: Financial results per aggregate economic agent in relation to GDP

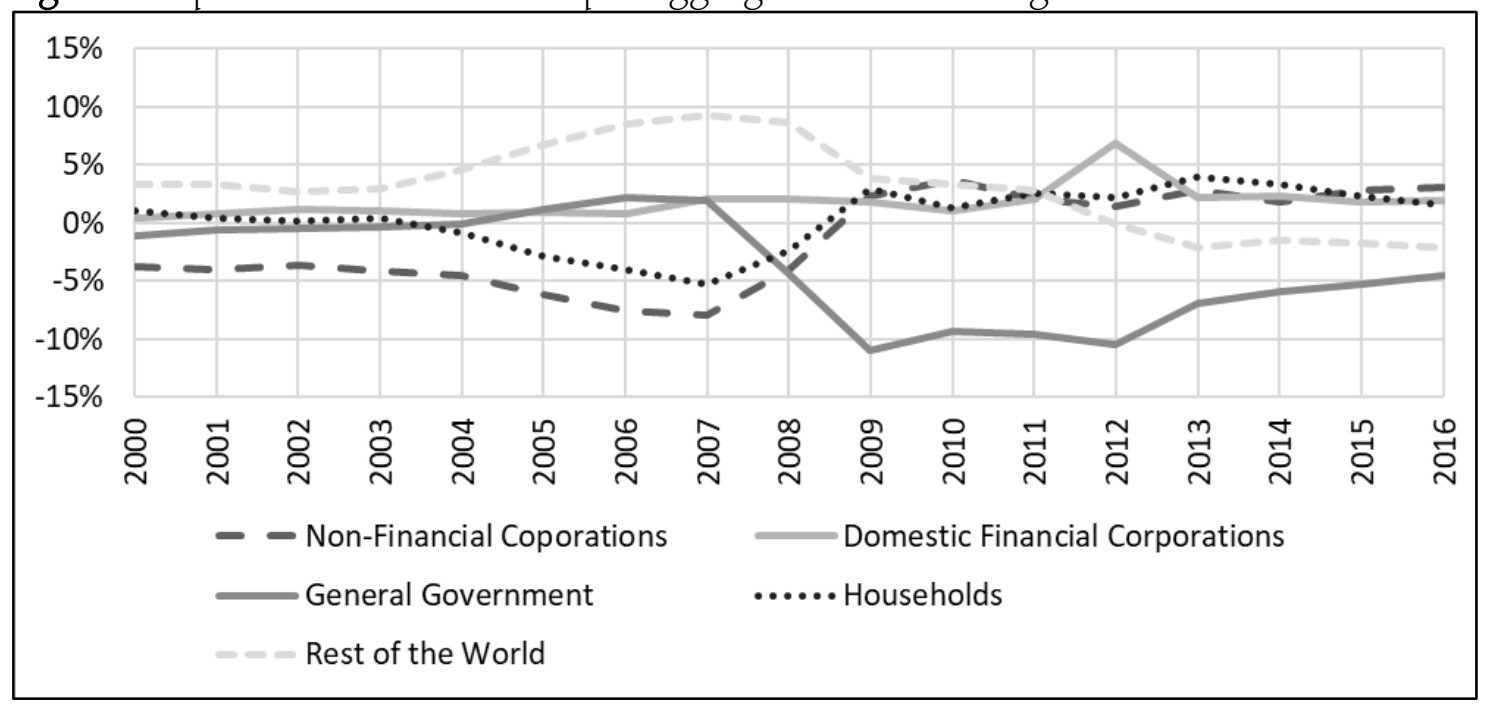

Source: Eurostat; own preparation. 
The consequences of the aforementioned financial results were the changes in the dynamics of indebtedness of the economic agents (Figure 10). The increases between 2000 and 2007 in the debts of households, non-financial corporations, and the financial sector - facilitated by financial liberalization - were accompanied by a reduction in public indebtedness. In the post-2008 period, the situation reversed: reduction in household indebtedness, stabilization of corporate and financial sector debt, and expansion of public debt.

Figure 10. Spain - Total liabilities per aggregate economic agent in relation to GDP

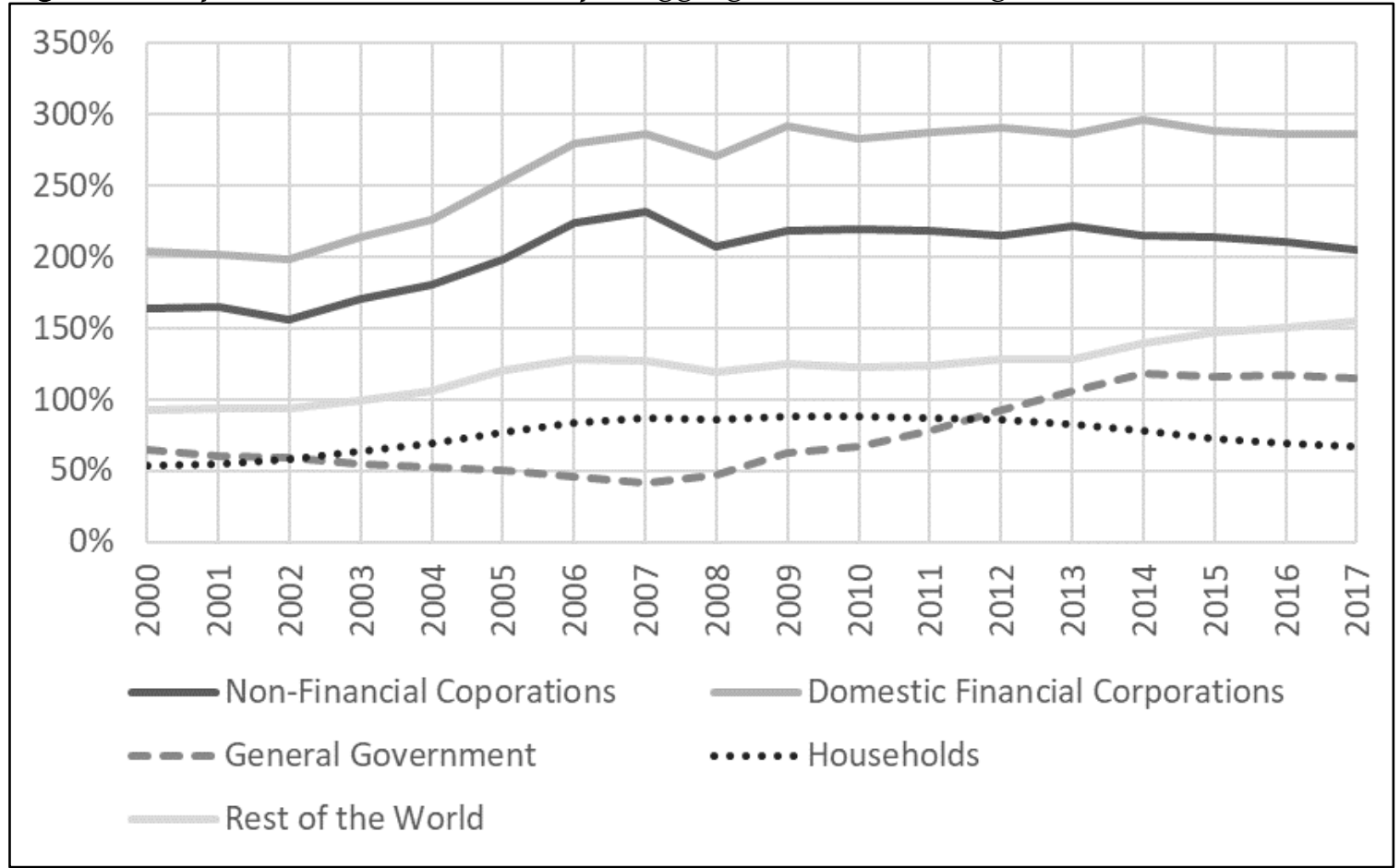

Source: Eurostat; own preparation.

\section{Conclusion}

The present article showed that although indebtedness is treated in the mainstream literature as only a slightly relevant element that is restricted - from the public viewpoint - to a limiting element of fiscal policy, post-Keynesian authors treat indebtedness as an element correlated to the expansion of demand, in accordance with the original ideas stated by Keynes and Minsky.

Thus, from 2000 to 2008, all GIIPS had a foreign sector in surplus (deficit in current accounts) that characterized distinct processes of indebtedness of the domestic economic agents. For Portugal and Italy, non-financial corporations remained in deficit in the period; for Ireland and Greece, households were the main deficit agent; and, in the case of Spain, both firms and households occupied a position of chronic deficit in the period. In all cases, the reversal of these processes 
was accompanied by larger public deficits and the replacement of private debts with public debt.

The small positive impacts on the economic performance of GIIPS between 2009 and 2017 came from the foreign sector, as a result of the devaluation of the euro in the period. The change in direction of the capital flows with the crisis generated a need for households and firms to reduce their indebtedness. However, this adjustment of the position of these agents in the face of the indebtedness is reflected in the decrease in domestic demand.

In this context, Ireland proved to be the only atypical case. Of the five countries, it was the only one to exhibit significant GDP growth between 2009 and 2017 - backed by export growth and, in particular, investment - and the high public deficit prevented the emergence of new private deficits. However, this result was achieved with a significant increase in corporate debt from just under $250 \%$ of GDP in 2008 to almost $700 \%$ in 2017.

Another important element that makes Ireland a special case is the high level of indebtedness of the foreign sector and financial institutions. This financial sector indebtedness is relatively common, given the extremely leveraged nature of this sector and its ability to create debt against itself (creation of fiduciary money by banks in the form of conceding credit). Additionally, the financial integration of the European bloc allowed economic agents to resort to different financial markets in the search for the best financing conditions. Even so, Ireland is the extreme case of the greater European financial integration, in which the agents outside the Irish economy are large borrowers of financing issued by its financial system, which, in turn, also reaches extremely high levels of indebtedness.

It is important to note that the same economic theory that neglected studies about the financial system and processes of private indebtedness (Pasinetti, 2012) shaped the economic policies for containing the expansion of public spending and public debt, since these would supposedly prevent the resumption of economic growth (Herndon et al., 2014; Reinhart and Rogoff, 2010).

Thus, with the exception of the Irish case, in view of the impossibility of growth of the components of the domestic absorption (consumption and/or investment due to the high private indebtedness of households and/or firms, and public spending due to hardly justifiable austerity policies), the slow post-crisis recovery was dependent on the reduction in export deficits (or rise in trade 
surpluses) driven by the real devaluation of the euro (consumer price index) and falling labor costs of GIIPS in relation to other eurozone countries.

\section{References}

Allen, W. A., \& Moessner, R. (2012). The liquidity consequences of the Euro Area sovereign debt crisis. In BIS working papers (No. 390).

Amitrano, C. (2013). Regime de crescimento, restrição externa e financeirização; uma proposta de conciliação. Economia e Sociedade, 22(2), 285-316. doi: 10.1590/S0104-06182013000200001

Arestis, P., \& Karakitsos, E. (2012). The U.S. dimension of the euro zone debt crisis. Journal of Post Keynesian Economics, 35(1), 21-44. doi: 10.2753/PKE01603477350102

Barro, R. J. (1974). Are government bonds net wealth? Journal of Political Economy, 82(6), 1095-1117. doi: 10.1086/260266

Barro, R. J. (1989). The Ricardian approach to budget deficits. Journal of Economic Perspectives, 3(2), 37-54. doi: 10.1257/jep.3.2.37

Bibow, J. (2013). The Euroland crisis and Germany's Euro trilemma. International Review of Applied Economics, 27(3), 360-385. doi: 10.1080/02692171.2012.721757

Boyer, R. (2000). Is a finance-led growtls a finance-led growth regime a viable alternative to Fordism? A preliminary analysis. Economy and Society, 29(1), 111-145.

Boyer, R. (2013). The Euro crisis: undetected by conventional economics, favoured by nationally focused polity. Cambridge Journal of Economics, 37(3), 533569. doi: $10.1093 /$ cje/bet013

Bresser-Pereira, L. C., \& Rossi, P. (2015). Sovereignty, the exchange rate, collective deceit, and the Euro crisis. Journal of Post Keynesian Economics, 38(3), 355-375. doi: 10.1080/01603477.2015.1087807

Cardim de Carvalho, F. J. (1999). On banks liquidity preference. In P. Davidson \& J. A. Kregel (Eds.), Full Employment and Price Stability in a Global Economy (1st ed.). Cheltenham: Edward Elgar Publishing.

Cardim de Carvalho, F. J. (2013). Keynes and the endogeneity of money. Review of Keynesian Economics, 1(4), 431-446. doi: 10.4337/roke.2013.04.05 
Cesaratto, S. (2013). The implications of TARGET2 in the European balance of payments crisis and beyond. European Journal of Economics and Economic Policies: Intervention, 10(3), 359-382. doi: 10.4337/ejeep.2013.03.09

Cesaratto, S. (2018). The nature of the eurocrisis. A reply to Febrero, Uxò and Bermejo. Review of Keynesian Economics, 6(2), 240-251. doi: 10.4337/roke.2018.02.05

Davidson, P. (1978). Money and the Real World. London: The Macmillan Press.

Davidson, P. (2009). John Maynard Keynes (2nd ed.). doi: 10.1057/9780230235472

Epstein, G. (2005). Financialization and the world economy. In Financialization and the World Economy. Cheltenham: Edward Elgar Publishing.

Fama, E. F. (1980). Banking in the Theory of Finance. Journal of Monetary Economics, 6, 39-57.

Farhi, M. (1999). Derivativos financeiros: hedge, especulação e arbitragem. Economia e Sociedade, 13, 93-114.

Febrero, E., Uxó, J., \& Bermejo, F. (2018). The financial crisis in the eurozone: a balance-of-payments crisis with a single currency? Review of Keynesian Economics, 6(2), 221-239. doi: 10.4337/roke.2018.02.04

Godley, W. (2012). Seven unsustainable processes: medium-term prospects and policies for the United States and the world. In M. Lavoie \& G. Zezza (Eds.), The Stock-Flow Consistent Approach (pp. 216-254). doi: 10.1057/9780230353848_11

Goodfriend, M., \& King, R. G. (1997). The New Neoclassical Synthesis and the Role of Monetary Policy. In Bernanke, Ben S \& Rotemberg, Julio, NBER Macroeconomics Annual 1997 (Vol. 12, p. 361). doi: 10.2307/3585232

Gurley, J. G., \& Shaw, E. S. (1955). Financial aspects of economic development. The American Economic Review, 45(4), 515-538. http://www.jstor.org/stable/pdf/1811632.pdf

Gurley, J. G., \& Shaw, E. S. (1956). Financial Intermediaries and the SavingInvestment Process. The Journal of Finance, 11(2), 257-276.

Guttmann, R., \& Plihon, D. (2010). Consumer debt and financial fragility. International Review of Applied Economics, 24(3), 269-283. doi: 10.1080/02692171003701420 
Hein, E. (2013). The crisis of finance-dominated capitalism in the euro area, deficiencies in the economic policy architecture, and deflationary stagnation policies. Journal of Post Keynesian Economics, 36(2), 325-354. doi: 10.2753/PKE0160-3477360207

Herndon, T., Ash, M., \& Pollin, R. (2014). Does high public debt consistently stifle economic growth? A critique of Reinhart and Rogoff. Cambridge Journal of Economics, 38(2), 257-279. doi: 10.1093/cje/bet075

Hicks, J. (1989). A market theory of money. Oxford: Oxford University Press.

Kaldor, N. (1939). Speculation and economic stability. The Review of Economic Studies, 7(1), 1-27.

Keynes, J. M. (2013). The General Theory of Employment, Interest and Money. Cambridge: Cambridge University Press.

Kregel, J. A. (1976). Economic methodology in the face of uncertainty: the modelling methods of Keynes and the Post-Keynesians. The Economic Jou, 86(342), 209-225. doi: 10.2307/2230743

Kregel, J. A. (1998). Aspects of a Post-Keynesian theory of finance. Journal of Post Keynesian Economics, 21(1), 111-133.

Lavoie, M. (2014). Post--Keynesian economics: new foundations (1st ed.). Cheltenham, UK: Edward Elgar.

Lavoie, M. (2015a). The Eurozone crisis: a balance-of-payments problem or a crisis due to a flawed monetary design? International Journal of Political Economy, 44(2), 157-160. doi:10.1080/08911916.2015.1060831

Lavoie, M. (2015b). The Eurozone: similarities to and differences from Keynes's plan. International Journal of Political Economy, 44(1), 3-17. doi: 10.1080/08911916.2015.1035980

Markowitz, H. (1952). Portfolio selection. The Journal of Finance, 7(1), 77-91. doi: 10.1111/j.1540-6261.1952.tb01525.x

Miller, M., \& Modigliani, F. (1961). Dividend policy, growth, and the valuation of shares. The Journal of Business, 34(4), 411-433.

Minsky, H. P. (2008a). John Maynard Keynes. New York: McGraw-Hill.

Minsky, H. P. (2008b). Stabilizing an unstable economy. New Haven: McGrawHill. 
Modigliani, F., \& Miller, M. (1958). The cost of capital, corporation finance and the theory of investment. The American Economic Review, 48(3), 261-297.

Mundell, R. A. (1961). A theory of optimum currency areas. The American Economic Review, 51(1), 657-665.

Özgür, G., \& Memis, E. (2017). Macroeconomic imbalances and the Eurozone crisis: the impact of credit expansion on asset prices. Review of Keynesian Economics, 5(3), 459-480. doi: 10.4337/roke.2017.03.07

Pasinetti, L. L. (2012). A few counter-factual hypotheses on the current economic crisis. Cambridge Journal of Economics, 36(6), 1433-1453. doi: 10.1093/cje/ber009

Reinhart, B. C. M., \& Rogoff, K. S. (2010). Growth in a time of debt. The American Economic Review, 100(2), 573-578. doi: 10.1257/aer.100.2.573

Thirlwall, A., \& McCombie, J. S. L. (2004). Essays on balance of payments constrained growth. doi: 10.4324/9780203495360

Tobin, J. (1958). Liquidity preference as behavior towards risk. The Review of Economic Studies, 25(2), 65-86.

Woodford, M. (2008). how important is money in the conduct of monetary policy? Journal of Money, Credit and Banking, 40(8), 1561-1598.

Woodford, M. (2009). convergence in macroeconomics: elements of the new synthesis. American Economic Journal: Macroeconomics, 1(1), 267-279. doi: $10.1257 / \mathrm{mac} \cdot 1.1 .267$

Wray, L. R. (2009). The rise and fall of money manager capitalism: a Minskian approach. Cambridge Journal of Economics, 33(4 SPEC. ISS.), 807-828. doi: 10.1093/cje/bep024 